\title{
EVALUATION OF ESTRUS AND PREGNANCY RATES IN FRIESIAN LACTATING COWS SYNCHRONIZED WITH MELENGESTEROL ACETATE-BASED PROTOCOLS
}

Abu EI - Hamd, M. A. ; A. M. Metwally²; Z. R. Ghallab², and M. A. El - Kramany ${ }^{1}$

1-Animal Production Research Institute, Agriculture Research Center, Dokki, Egypt,

2-Department of Animal Production, Faculty of Agriculture, Kafr Elsheikh University, Egypt.

\begin{abstract}
The objective of this study was to evaluate estrus synchronization and pregnancy rate of Friesian lactating cows during postpartum period in melengesterol acetate (MGA) based protocols for estrus synchronization. The total 30 dairy cows were used in this study, average age between 25-68 months and weighting 440 - 620 $\mathrm{kg}$ and 1-5 parities was used in this study. At the beginning of the experimental period, the experimental cows were divided \}\}\}into three similar groups, 10 in each. Cows in the $1^{\text {st }}$ treatment were fed on $0.5 \mathrm{~g} \mathrm{MGA} /$ cow/day for 14 days. In the $2^{\text {nd }}$ treatment, cows were fed on $0.5 \mathrm{~g} \mathrm{MGA} / \mathrm{cow} /$ day for 14 days followed 33 days later by injection with $3 \mathrm{ml} \mathrm{PGF} 2 \mathrm{a}$. In the $3^{\text {rd }}$ treatment, cows were fed $0.5 \mathrm{~g} \mathrm{MGA} / \mathrm{cow} /$ day for to 14 days followed 26 intramuscularly injected with the $1^{\text {st }}$ dose of $5 \mathrm{ml} \mathrm{GnRH}$, followed 33 days injected with $3 \mathrm{ml} \mathrm{PGF}_{2 \alpha}$ followed 36 days injected with the $2^{\text {nd }}$ dose $\mathrm{GnRH}$ and fixed-time insemination. Results revealed that estrus response after the end of hormonal protocols were statistically $(P<0.05)$ significantly higher in MGA and MGA+PGF $2 \alpha$ protocols $(90 \%)$ than the MGA select protocol $(70 \%)$. Pregnancy rates assessed in all cows after Al tended to be higher (90\%) for the MGA+PGF $2 a$ protocol and moderate in MGA select protocol $(80 \%)$ than in the MGA protocol being for lower (70\%). Progesterone concentration (P4) was above $1 \mathrm{ng} / \mathrm{ml}$ in all treated animals pretreatment ranging $2.308-3.073 \mathrm{ng} / \mathrm{ml}$. After the oral feeding MGA $0.5 \mathrm{~g} / \mathrm{cow} / \mathrm{day}, \mathrm{P} 4$ concentration at days of 7 and 14 was increased in all animals of different protocols than in all animals in pre-treatments. On day 24 post-service, concentration of P4 was higher in responded animals, indicating incidence of pregnancy which were conceived after the $\mathrm{PGF}_{2} \alpha$ injection in MGA+PGF $2 \alpha$ protocol and $\mathrm{GnRH}$ injection of MGA select protocol. The economic evaluation indicated that MGA protocol had the cheapest cost (L.E 4.9/cow), followed by MGA+PGF $2 \alpha$ protocol (L.E 16.9/cow). While, MGA select protocol showed the highest cost (L.E 56.9/cow).

In conclusions cows treated by $\mathrm{MGA} \mathrm{PGF}_{2 \alpha}$ protocol at insemination based on heat incidence to improve their reproductive performance. From the economic point of view, MGA+PGF $2 \alpha$ protocol showed the best results (conception rate and costs) compared to the other protocols.
\end{abstract}

Keywords: Friesian cows, MGA, GnRH, $\mathrm{PGF}_{2} \alpha$, conception rate and progesterone.

\section{INTRODUCTION}

Reproductive efficiency is essential in well-managed and profitable dairy farms (Nebel and Jobst, 1998). Optimal economic returns can be achieved in the dairy industry when cows conceive early with three or fewer breeding (Short and Bellows, 1971). 
Melengestrol acetate (MGA), a synthetic progestagen, has been used in various regimens to synchronize estrus in cattle (Patterson et al., 1989 and Odde, 1990).

The MGA/prostaglandin (PGF) method of estrous synchronization has proven to be very successful in synchronizing estrus in beef heifers (Patterson and Corah, 1992). One disadvantage to the MGA/PGF protocol is that MGA must be fed for 14 day followed 17-19 day later withy an injiection of PGF (Lamb et al., 2000). However, when MGA is fed in the absence of a functional corpus luteum (CL), a dominant follicle persists and fertility at the ensuing estrus is reduced (Custer et al., 1994 and Patterson et al., 1989). The development of persistent follicles may be prevented by strategically synchronizing follicular wave emergence; either GnRH or estradiol-17ß (E$17 B$ ) and progesterone have been given on the first day of a short-term (7- or 8-day) MGA regimen to synchronize emergence of a new wave (Kastelic et al., 1997 and Thundathil et al., 1999).

Stegner et al. (2004a) discussed the advantages and disadvantages related to practical application and successful administration of the MGA Select and 7-11 Synch protocols. The advantages shown here and reported in other studies include the following: 1) MGA is economical to use (approximately $\$ 0.02$ per animal daily to feed); 2) each protocol works effectively in mixed populations of beef cows that were estrous cycling or anestrus at the time treatments are imposed; and 3) pregnancy rates resulting from insemination performed on the basis of detected estrus or at predetermined fixed times are comparable and highly acceptable (Patterson et al., 2005).

In the recent years, $\mathrm{GnRH}$ and Prostaglandin $\mathrm{F}_{2 \alpha}\left(\mathrm{PGF}_{2 \alpha}\right)$ have been used in various combinations to increase reproductive efficiency in lactating dairy cows and heifers (Yaniz et al., 2004).

The anabolic mode of action of MGA is assumed to be due to stimulation of the ovarian synthesis of endogenous estradiol (Hageleit et al., 2000). Androgenic side effects are probably not of concern because a recent study has shown that the binding affinity of MGA to the rhAR is only about $1 \%$ of testosterone and $0.3 \%$ of dihydrotestosterone (Bauer et al., 2000).

Therefore, the aim of the current study was to evaluate estrus synchronization and pregnancy rate of Friesian lactating cows during postpartum period in MGA based protocols for estrus synchronization.

\section{MATERIALS AND METHODS}

The present study was carried out at Sakha Animal Production Research Station, belonging to the Animal Production Research Institute, Agricultural Research Center, Ministry of Agriculture and Land Reclamation, Egypt during the period from October, 2012 till April, 2013.

Animals:

Total of 30 cows were used in this study, aging between $25-68$ months and weighing $440-620 \mathrm{~kg}$ and $1-5$ parities was used in this study. At the beginning of the experimental period, the experimental cows were divided 
into three similar groups, 10 in each. Mutiparous cows ( $\mathrm{n}=19$ in all groups) were divided according to their BW, parity and milk production of the previous season, while primiparous cows ( $n=11$ in all groups) were allotted based only on their BW. All cows were chosen at postpartum period (40 days post calving).

Experimental cows were fed a diet containing concentrate feed mixture, rice straw and corn silage according to the recommendation of NRC (2001) for dairy cows based on their live body weight and milk yield.. All cows free of any diseases with healthy appearance and they were housed in separated two groups under semi-open sheds, partially roofed by asbestos Treatment protocols:

Cows in the $1^{\text {st }}$ treatment of miparous cows $(n=3)$ and mutiparous cows $(n=7)$ were cows were feeding $0.5 \mathrm{~g} \mathrm{MGA} / \mathrm{cow} /$ day for to 14 days (Diagram 1).

In the $2^{\text {nd }}$ treatment, miparous cows $(n=4)$ and mutiparous cows $(n=6)$ were feeding $0.5 \mathrm{~g} \mathrm{MGA} / \mathrm{cow} /$ day for to 14 days followed 33 days later by injection with $3 \mathrm{ml} \mathrm{PGF} 2 \alpha$ analogue (Synchromate Bremer Pharma 27540 Bremerhaven Germany) containing (0.750 $\mu \mathrm{g}$ cloprostenol), thereafter animals were observed for oestrus signs and those in heat were served (Diagram 1).

In the $3^{\text {rd }}$ treatment, primiparous cows $(n=4)$ and mutiparous cows $(n=6)$ were feeding $0.5 \mathrm{~g} \mathrm{MGA} / \mathrm{cow} /$ day for to 14 days followed 26 intramuscularly injected with the $1^{\text {st }}$ dose of $5 \mathrm{ml} \mathrm{GnRH}$ analogue (Receptal, Hoechst, Germany) containing $20 \mu \mathrm{g} \mathrm{GnRH}$, followed 33 days injected with 3 $\mathrm{ml}$ synchromate $\left(\mathrm{PGF}_{2 \alpha}\right.$ analogue), followed 36 days injected with the $2^{\text {nd }}$ dose $\mathrm{GnRH}$ analogue with $5 \mathrm{ml} \mathrm{GnRH}$ analogue (Receptal, Hoechst, Germany) containing $20 \mu \mathrm{g} \mathrm{GnRH}$ and fixed time insemination after $72 \mathrm{~h}$ injected with the $2^{\text {nd }}$ dose $\mathrm{GnRH}$ (Diagram 1).

Blood sampling:

Blood samples were collected 8,4 and 1 day before initiation of MGA feeding to determine pretreatment concentrations of progesterone and oestradiol-17 $\beta$ in blood serum of cows. In during treatment period, blood samples were collected twice weekly, at 3-4 days interval via the jugular vein from all the experimental cows for determination of progesterone (P4) and oestradiol-17 $\beta$ in blood serum. Within an hour after collection, samples were centrifuged for 15 minutes at $3000 \mathrm{rpm}$ for serum separation. Serum samples were stored at $-20 \stackrel{\circ}{ } \mathrm{C}$ till the $\mathrm{P} 4$ assay.

\section{Progesterone assay:}

Direct radioimmunoassay technique (RIA) was performed for determination of $\mathrm{P} 4$ concentration in blood serum using ready antibody coated tubes kit (Diagnosis Systems Laboratories, Texas, USA) according to the procedure outlined by the manufacturer.

According to the manufacture's information, the cross reaction of progesterone antibody (at $50 \%$ binding), was $100 \%$ with progesterone while was $6.00,2.50,1.20,0.80,0.48$, and $0.10 \%$ with $5 \alpha$-pregnone-3, 20-dione 11-Deoxycorticosterone, 17 $\alpha$-Hydroxyprogesterone, $5 \beta$-pregnone-3, 20-dione 
11-Deoxycortisol, and 20a-Dihydroxyprogesterone, respectively and less than $0.1 \%$ with any of the other steroids.

The standard curve of $\mathrm{P} 4$ ranged from 0.0 to $40.0 \mathrm{ng} / \mathrm{ml}$. The sensitivity value was reported to be $0.12 \mathrm{ng} / \mathrm{ml}$. The intra and inter-assay coefficients of variation were $8.0 \%$ and $13.1 \%$.

\section{Oestradiol-17 $\beta$ radioimmunoassay:}

Oestradiol-17 $\beta$ concentrations were determined by the radioimmunoassay procedure previously reported by Sirois and Fortune (1990). The intra-assay coefficient of variation for oestradiol-17 $\beta$ was $4.0 \%$ when calculated from duplicates of the entire material. The inter-assay coefficient of variation was $10.9 \%$ (116.3 pmol//). The detection limit of the assay was $2.9 \mathrm{pmol} / \mathrm{l}$.

\section{Statistical Analysis:}

To compare between within each treatment group, results of P4 concentration were statistically analyzed according to Snedecor and Cocharn (1989) and the statistical model was:

Where:

$$
Y_{i j}=U+A_{i}+e_{i j} \text {. }
$$

$Y_{i j}=$ Observed values.

$U=$ Overall mean

$A_{i}=$ Animals (conceived and non- conceived).

$\mathrm{e}_{\mathrm{ij}}=$ Random error .

Chi-square was used to test the differences in conception rate among treatment protocols. Duncan Multiple Range test (Duncan, 1955) was used to get the mean separations among treatment protocols for total cost/animal.

\section{RESULTS AND DISCUSSION}

The percentages of cows observed in estrus response after the end of hormonal protocols were $90 ; 90$ and $70 \%$ for the MGA alone, MGA+PGF $2 a$ and MGA select protocols, respectively. The differences among groups were statistically $(P<0.05)$ significantly higher in $M G A$ and $M G A+P G F_{2 \alpha}$ protocols $(90 \%)$ than the MGA select protocol $(70 \%)$. These in MGA and MGA+PGF $2 a$ protocols provide a consistently high estrous response and predictable synchrony of estrus. Treatment differences in serum concentrations of progesterone at $\mathrm{PGF}_{2 \alpha}$ on $\mathrm{d} 33$ in this experiment are likely a function of $\mathrm{MGA}+\mathrm{PGF}_{2 \alpha}$ protocol.

Feeding an oral MGA suppresses estrus by inhibiting the ovulatory surge of luteinizing hormone (LH) (Yelich et al., 1997), it also has the potential of inducing estrus in prepubertal heifers (Patterson et al., 1989).

Pregnancy rates assessed in all cows by rectal palpation on day 60 after $\mathrm{Al}$ tended to be higher (90\%) for the MGA+PGF $2 \alpha$ and moderate in MGA select protocols than for lower in the MGA protocol being $70 \%$, (Table 2 ) in the $1^{\text {st }}$ estrus. 
Table (1): Estrous and pregnancy rates of cows treated with different protocols

\begin{tabular}{|c|c|c|c|}
\hline \multirow{2}{*}{ Item } & \multicolumn{3}{|c|}{ Hormonal protocol } \\
\cline { 2 - 4 } & $\begin{array}{c}\text { MGA } \\
\text { protocol }\end{array}$ & MGA+PGF $_{2 \alpha}$ protocol & $\begin{array}{c}\text { MGA select } \\
\text { protocol }\end{array}$ \\
\hline Number treated & 10 & 10 & 10 \\
\hline Estrous rate (\%) & $90^{\mathrm{a}}$ & $90^{\mathrm{a}}$ & $70^{\mathrm{b}}$ \\
\hline Pregnancy (\%) & $70^{\mathrm{b}}$ & $90^{\mathrm{a}}$ & $80^{\mathrm{ab}}$ \\
\hline
\end{tabular}

$a$ and $b$ :Means denoted within the same column, with different superscripts are significantly different at $\mathbf{P}<0.05$.

Generally, the obtained high $\mathrm{CR}$ in this study after the $1^{\text {st }} \mathrm{PGF}_{2} \mathrm{\alpha}$ injections after feed MGA of 19 day was attributed to an appropriate time of oestrus incidence and consequently good time of insemination and fertilization. Repasi et al. (2006) found that more cows became pregnant $(P>0.05)$ if they were inseminated within 4 days after $P F_{2} \alpha$ treatment.

Feeding MGA at $0.5 \mathrm{mg} / \mathrm{head} /$ day for $14 \mathrm{~d}$ followed by $\mathrm{PGF}_{2 \alpha}$ injection 17 day after MGA withdrawal has been an effective of estrous cycle control in heifers (Brown et al. 1988). The MGA regime resulted in a higher percentage of cows in estrus and comparable pregnancy rates when compared to an MGA-PGF $2 a$ (Wright et al., 2001). When used in combination with an MGA$\mathrm{PGF}_{2 \alpha}$ synchronization program, gonadotropin releasing hormone $(\mathrm{GnRH})$ has decreased the time to estrus and given the potential for fixed-time insemination (Wood et al. 2001). Injecting cows at random stages of the estrous cycle with $\mathrm{GnRH}$ causes a luteinizing hormone $(\mathrm{LH})$ release, which leads to ovulation.

In MGA+PGF $2 \alpha$ protocol, prostaglandin should be administered 19 days after the last day of MGA feeding. This treatment places all animals in the late luteal stage of the estrous cycle at the time of PG injection, the synchronized period and conception rate. Although a 19-day interval is optimal, 17- to 19day intervals produce acceptable results and provide flexibility for extenuating circumstances (Brown et al., 1988; Deutscher, 2000 and Lamb et al., 2000).

The fertility after treatment MGA Select protocol was shown to produce pregnancy rates resulting from fixed-time Al consistently ranging from 54 to 72\% (Patterson et al., 2005).

The MGA Select protocol results in a consistent synchrony of estrus with the peak estrous response typically occurring $72 \mathrm{~h}$ after the administration of PG (Patterson et al., 2002 and Stegner et al., 2004b). Furthermore, pregnancy rates following administration of the MGA Select protocol and resulting from fixed-time Al have consistently run $\geq 60 \%$, when Al was performed $72 \mathrm{~h}$ after PG (Perry et al., 2002; Stegner et al., 2004c and Bader et al., 2005). The pregnancy rates resulting from fixed-time Al reported in this study following treatment with the MGA Select estrus synchronization protocol are consistent with other published data when insemination was performed $72 \mathrm{~h}$ after PG (Perry et al., 2002; Stegner et al., 2004c and Bader et al., 2005). The MGA Select protocol have been shown to reliably induce estrous cyclicity, improve estrous response, and increase pregnancy rates during the synchronized period in anestrous and estrous cycling cows (Kojima et al., 2000 and Patterson et al., 2002). 
In study MGA select protocol (timed Al) was improved pregnancy rates compared with MGA protocol for both lactating cows. The results shown that Kastelic et al., (1997), who that feeding MGA after timed Al, significantly improved pregnancy rates compared with untreated controls for both heifers ( 4 of 9 vs. 0 of 7 ) and cows ( 6 of 11 vs. 1 of 9). Similarly, significant increases in pregnancy rates have been reported when progestagen supplementation was given after breeding when pregnancy rates in untreated cattle were relatively low (Van Cleeff et al. 1991).

\section{Progesterone profile}

Concerning progesterone (P4) profile pre-, during and post-treatment of all protocols shown in Table 2. The P4 concentration was above $1 \mathrm{ng} / \mathrm{ml}$ in all treated animals pre-treatment ranging $2.308-3.073 \mathrm{ng} / \mathrm{ml}$. After the oral feeding MGA $0.5 \mathrm{~g} / \mathrm{cow} /$ day, P4 concentration at days of 7 and 14 was increased in all animals of different protocols than in all animals in pretreatments (Table 2).

In day 36-38, P4 level markedly decreased below $1 \mathrm{ng} / \mathrm{ml}$ in animals responded to oestrus in MGA+PGF $2 a$ and MGA select protocols $(0.26$ and $0.604 \mathrm{ng} / \mathrm{ml}$, respectively) than in MGA protocol $(1.12 \mathrm{ng} / \mathrm{ml})$ as a result of $\mathrm{CL}$ regression, initiation of new follicular wave and onset of oestrus. However, level of P4 was higher in non-responded cows (Fig. 1-4), indicating no incidence of oestrous or silent ovulation in this animal. On day 24 postservice, concentration of P4 was higher in responded animals, indicating incidence of pregnancy which were conceived after the $\mathrm{PGF}_{2} \alpha$ injection in $M G A+P F_{2 a}$ protocol and $G n R H$ injection of MGA select protocol and then fixed-time Al, 16 to $24 \mathrm{~h}$ after the second $\mathrm{GnRH}$ treatment (Table 2).

Table (2): Progesterone profile $(\mathrm{ng} / \mathrm{ml})$ in different period treatment.

\begin{tabular}{|l|c|c|c|c|}
\hline \multirow{2}{*}{\multicolumn{1}{|c|}{ Item }} & \multicolumn{3}{|c|}{ Hormonal protocol } & \multirow{2}{*}{ SEM } \\
\cline { 2 - 4 } & $\begin{array}{c}\text { MGA } \\
\text { protocol }\end{array}$ & $\begin{array}{c}\text { MGA+PGF }_{2 a} \\
\text { protocol }\end{array}$ & $\begin{array}{c}\text { MGA select } \\
\text { protocol }\end{array}$ & \\
\hline Pre-treatment & 2.967 & 3.073 & 2.308 & 0.43 \\
\hline Day 7 during-treatment & $3.939^{\mathrm{b}}$ & $6.907^{\mathrm{a}}$ & $4.575^{\mathrm{b}}$ & 0.70 \\
\hline Day 14 during-treatment & $3.263^{\mathrm{b}}$ & $6.131^{\mathrm{a}}$ & $5.624^{\mathrm{a}}$ & 0.62 \\
\hline Day 26 during-treatment & $4.312^{\mathrm{b}}$ & $6.796^{\mathrm{a}}$ & $4.035^{\mathrm{b}}$ & 0.63 \\
\hline Day 33 during-treatment & $3.709^{\mathrm{ab}}$ & $5.294^{\mathrm{a}}$ & $3.140^{\mathrm{b}}$ & 0.65 \\
\hline Day 36 during-treatment & 1.120 & 0.260 & 0.604 & 0.48 \\
\hline 24 days post-service & 7.807 & 8.506 & 7.716 & 0.83 \\
\hline
\end{tabular}

$a$ and $b$ :Means denoted within the same column, with different superscripts are significantly different at $\mathrm{P}<0.05$.

Concentration of P4 during synchronized period and post- treatments in deferent protocols were shown in Figure 2, 3 and 4. In Figure 2 shown P4 concentration in animals of MGA protocol (conceived and non-conceived). However, P4 in MGA+PGF $2 \alpha$ and MGA select protocols were show in Figure 3 and 4, respectively. The P4 level pre- and post-injection as well as on day 24 post-service showed similar trend to those animals conceived.

Concentrations of $\mathrm{P} 4$ at 7,33 and 26 day significantly higher $(P<0.05)$ in $M G A+P G F_{2 a}$ protocol than in MGA and MGA select protocols, 
however in day 14 higher in MGA+PGF $2 \alpha$ and MGA select protocols than in MGA protocol (Table 2).

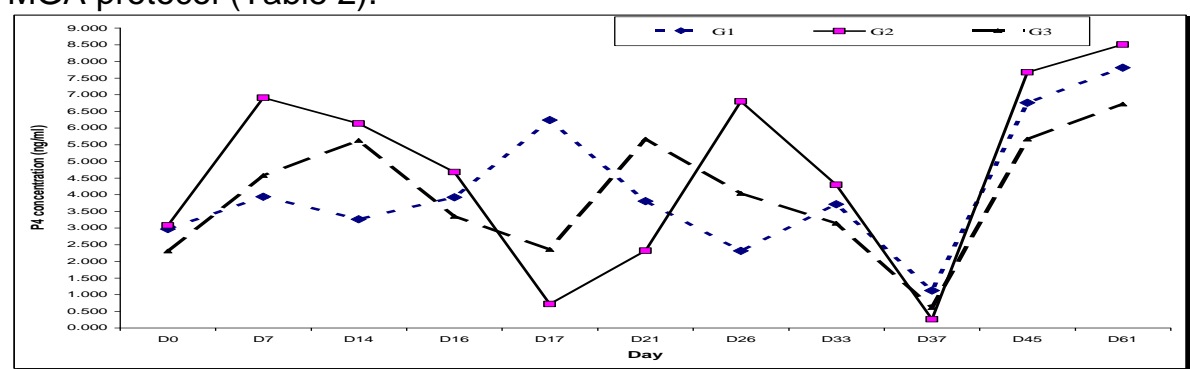

Fig. (1): Progesterone profile in cow of different protocols.

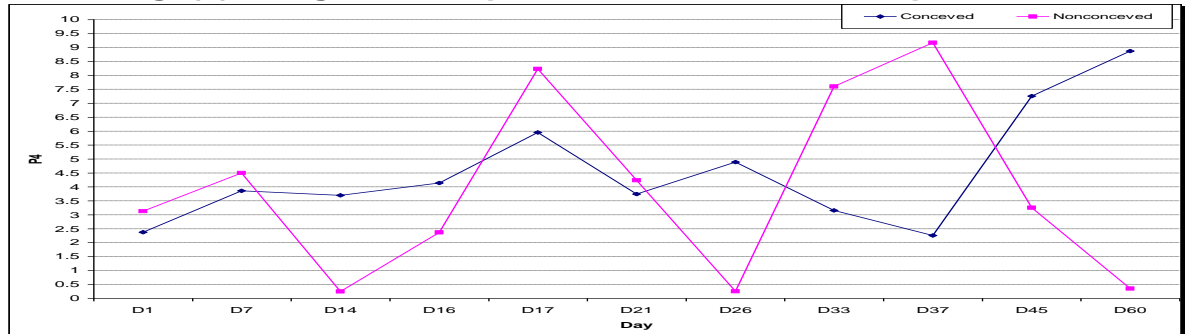

Fig. (2): Progesterone profile in cow of MGA protocol.

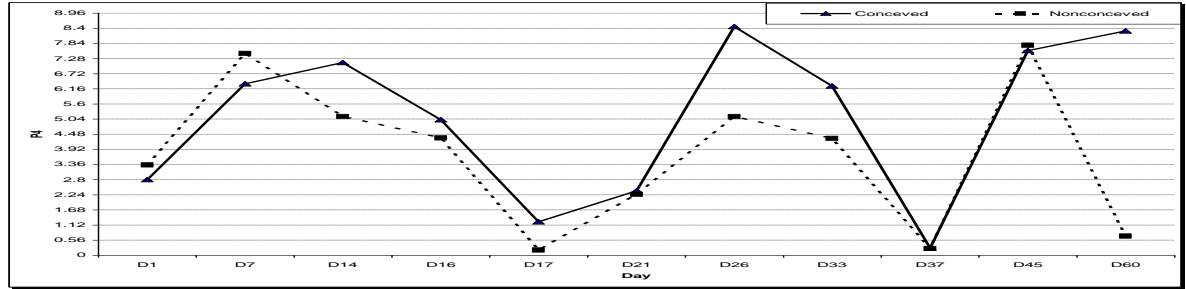

Fig. (3): Progesterone profile in cow of MGA+PGF $2 \alpha$ protocol

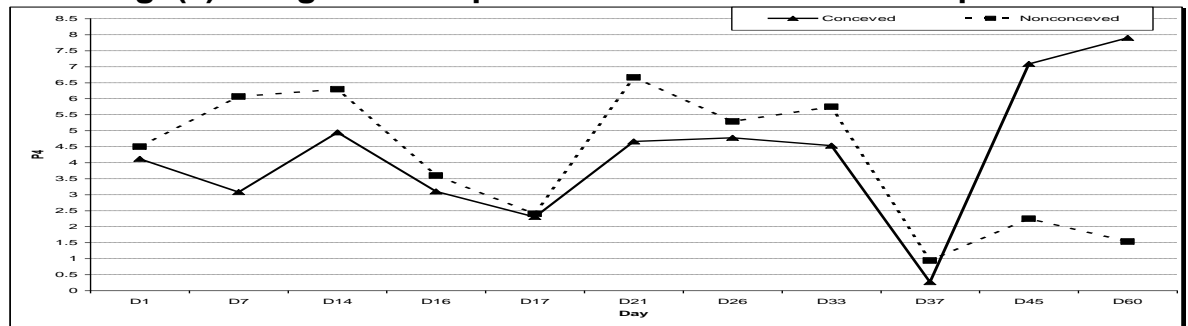

Fig. (4): Progesterone profile in cow of MGA select protocol Oestradiol-17 $\beta$ profile:

Results in table (3) shown that oestradiol-17 $\beta$ concentration pre- and during the treatments in all cows were significant in different protocol during period experimental. Oestradiol- $17 \beta$ concentration was significantly $(P<0.05)$ higher at pre-treatment and day 14 and 33 of treatment in MGA Protocol and MGA+PGF $2 a$ protocol than in MGA select protocol (Table 3 and Fig 5).

Melengestrol acetate, a synthetic progestin, has been used in various regimens for estrus synchronization (Patterson et al. 1989 and Odde 1990). 
In one synchronization regimen, MGA is fed for $7 \mathrm{~d}$ (days 1 to 7 ) with PGF given on day 7 (Beal et al. 1988). This regimen effectively synchronizes estrus, but pregnancy rates are lower in cattle that are late in the estrous cycle at the start of MGA treatment compared with those that are early. When this regimen is started late in the estrous cycle, the corpus luteum regresses, a dominant ovarian follicle becomes large and persists, and plasma estrogen concentrations increase (Custer et al. 1994 and Kojima et al. 1995). Treatment with E17causes atresia of the existing large ovarian follicles and results in emergence of a new follicular wave, on average, $4.3 \mathrm{~d}$ after treatment (Bo et al. 1995). Progesterone $(100 \mathrm{mg}$ ) is given with the $\mathrm{E} 17$ to prevent an estrogen-induced LH surge in cattle without a functional corpus luteum (Bo et al. 1994). Treatment with $\mathrm{GnRH}$ has been shown to cause ovulation or atresia of large antral follicles (regardless of the stage of the estrous cycle), with a new follicular wave emerging approximately $2 \mathrm{~d}$ after treatment (Twagiramungu et al. 1994). In most synchronization regimens utilizing GnRH, PGF is given 6 or $7 \mathrm{~d}$ later followed by a second $\mathrm{GnRH}$ treatment 30 to $48 \mathrm{~h}$ after PGF and then fixed-time Al, 16 to $24 \mathrm{~h}$ after the second $\mathrm{GnRH}$ treatment (Twagiramungu et al. 1995).

Table (3): Oestradiol-17 $\beta$ profile $(\mathrm{ng} / \mathrm{ml})$ in different period treatment.

\begin{tabular}{|c|c|c|c|c|}
\hline \multirow[b]{2}{*}{ Item } & \multicolumn{3}{|c|}{ Hormonal protocol } & \multirow[b]{2}{*}{ SEM } \\
\hline & $\begin{array}{c}\text { MGA } \\
\text { protocol }\end{array}$ & $\begin{array}{c}\mathrm{MGA}^{\mathrm{M}}+\mathrm{PGF}_{2 \alpha} \\
\text { protocol }\end{array}$ & $\begin{array}{c}\text { MGA } \\
\text { select } \\
\text { protocol }\end{array}$ & \\
\hline Pre-treatment & $1.716^{\mathrm{a}}$ & $1.558^{\mathrm{a}}$ & $0.437^{b}$ & 0.19 \\
\hline Day 7 during-treatment & 1.819 & 2.280 & 1.805 & 0.37 \\
\hline Day 14 during-treatment & $2.455^{a}$ & $2.365^{a}$ & $1.618^{b}$ & 0.23 \\
\hline Day 26 during-treatment & 2.893 & 2.113 & 2.185 & 0.43 \\
\hline Day 33 during-treatment & $2.638^{a}$ & $2.309^{a}$ & $1.799^{b}$ & 0.27 \\
\hline Day 36 during-treatment & 6.430 & 7.625 & 6.235 & 0.52 \\
\hline
\end{tabular}

$a$ and $b$ :Means denoted within the same column, with different superscripts are significantly different at $\mathbf{P}<0.05$.

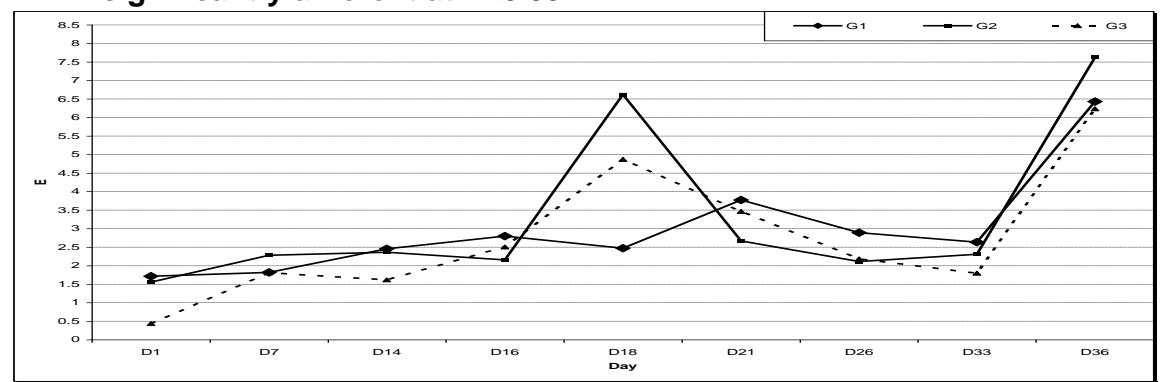

Fig. (5): Oestradiol-17 $\beta$ profile in cow of different protocols.

\section{Comparison among protocols:}

From the reproductive point of view, 24 out of 30 treated cows $(80 \%)$ were conceived using all hormonal protocols, being the highest in MGA+PGF $2 \alpha$ protocol $(90 \%)$, moderate $(80 \%)$ in MGA select protocol and the 
lowest $(70 \%)$ in MGA protocol. While, the economic evaluation indicated that MGA protocol had the cheapest cost (L.E 4.9/animal), followed by MGA+PGF $2 a$ protocol (L.E 16.9/animal), and while MGA select protocol showed the highest cost (L.E 56.9/animal, Table 4).

Table (4): Reproductive evaluation and economic efficiency of different hormonal treatments.

\begin{tabular}{|c|c|c|c|}
\hline \multirow[b]{2}{*}{ Item } & \multicolumn{3}{|c|}{ Hormonal protocol } \\
\hline & $\begin{array}{c}\text { MGA } \\
\text { Protocol }\end{array}$ & $\begin{array}{c}\mathrm{MGA}+\mathrm{PGF}_{2 \alpha} \\
\text { protocol }\end{array}$ & $\begin{array}{l}\text { MGA select } \\
\text { protocol }\end{array}$ \\
\hline \multicolumn{4}{|c|}{ Reproductive evaluation of treatment: } \\
\hline Treated animals $(n)$ & 10 & 10 & 10 \\
\hline Conceived animals (n) & 7 & 9 & 8 \\
\hline Non conceived (n) & 3 & 1 & 2 \\
\hline Conception rate (\%) & 70 & 90 & 80 \\
\hline \multicolumn{4}{|c|}{ Economic efficiency of treatment: } \\
\hline Treatment period (day) & 14 & 33 & 36 \\
\hline Price of MGA treatment (L.E) & 4.9 & 4.9 & 4.9 \\
\hline Price of $1^{\text {st }}$ injection (L.E) & - & 12 & 20 \\
\hline Price of $2^{\text {nd }}$ injection (L.E) & - & - & 12 \\
\hline Price of $3^{\text {rd }}$ injection (L.E) & - & - & 20 \\
\hline $\begin{array}{l}\text { Total cost of protocol } \\
\text { (L.E/animal) }\end{array}$ & $4.9 \pm 2.24^{b}$ & $16.9 \pm 2.24^{a}$ & $56.9 \pm 2.24^{a}$ \\
\hline
\end{tabular}

Price of one kg of MGA was 700 L.E. Price of each injection from GnRH and $\mathrm{PGF}_{2} \alpha$ was L.E 20 and 12, respectively.

\section{CONCLUSION}

The current study indicated that some differences between protocols and average $\mathrm{P} 4$ concentration during oestrous cycle, being with higher values in conception rate in cows. Cows treated by $\mathrm{MGA} \mathrm{PGF}_{2 a}$ protocol at insemination based on heat incidence to improve their reproductive performance. From the economic point of view, MGA+PGF $2 a$ protocol showed the best results (conception rate and costs) compared to the other protocols.

\section{REFERENCES}

Bader, J.F., F.N. Kojima, D.J. Schafer, J.E. Stegner, M.R. Ellersieck, M.F. Smith and D.J. Patterson. 2005. A comparison of two progestin-based protocols to synchronizeovulation and facilitate fixed-time artificial insemination in postpartum beef cows.J.Anim.Sci.,83:136-143.

Bauer, E.R.S., A. Daxenberger, T. Petri, H. Sauerwein, H.H.D. Meyer. 2000. Characterisation of the affinity of different anabolics and synthetic hormones to the human androgen receptor, human sex hormone binding globulin and to the bovine progestin receptor. J. Apmis, vol. 108, (12): 838-846.

Beal, W.E., J.R. Chenault, M.L. Day and L.R. Corah. 1988. Variation in conception rates following synchronization of estrus with melengestrol acetate and prostaglandin F2a. J. Anim. Sci., 66: 599-602. 
Bo, G.A., Adams, G.P., Pierson, R.A. and Mapletoft, R. J. 1995. Exogenous control of follicular wave emergence in cattle. Theriogenology, 43: 3140.

Bo, G.A., G.P. Adams, R.A. Pierson, M. Caccia, H. Tribulo and R.J. Mapletoft. 1994. Follicular wave dynamics after estradiol-17 $\beta$ treatment of heifers with or without a progestagen implant. Theriogenology, 41: $1555-1569$.

Brown, L.N., K.G. Odde, D.G. LeFever, M.E. King and C.J. Neubauer. 1988. Comparison of MGA-PGF2 $\alpha$ to Syncro-Mate $B$ for estrous synchronization in beef heifers. Theriogenology, 30:1.

Custer, E.E., W.E. Beal, S.J. Wilson, A.W. Meadows, J.G. Berardinelli and R. Adair, R. 1994. Effect of melengestrol acetate (MGA) or progesteronereleasing intravaginal device (PRID) on follicular development, concentrations of estradiol-17b and progesterone and luteinizing hormone release during an artificially lengthened bovine estrous cycle. J. Anim. Sci. 72: 1282-1289.

Deutscher, G.H. 2000. Extending interval from seventeen to nineteen days in the melengestrol acetate-prostaglandin estrous synchronization program for heifers. Prof. Anim. Sci., 16:164-168.

Duncan, D. B. 1955. Multiple ranges and multiple F-test. Biometrics, 11:1-42.

Hageleit. M., A. Daxenberger, W.D. Kraetzl, A. Kettler and H.H.D. Meyer. 2000. Dose-dependent effects of melengestrol acetate (MGA) on plasma levels of oestradiol, progesterone and luteinising hormone in cycling heifers and influences on oestrogen residues in edible tissues. APMIS 108: 847-854.

Kastelic, J.P., D.H. McCartney, W.O. Olson, A.D. Barth and R.J. Mapletoft. 1997. Melengestrol acetate (MGA) and estradiol-17b for synchronizing estrus and improving reproductive performance in beef cattle. Can. J. Anim. Sci., 77: 683-688.

Kojima, F.N., J.R. Chenault, M.E. Wehrman, E.G. Bergfeld, A.S. Cupp, L.A. Werth, V. Mariscal, T. Sanchez, R.J. Kittok and J.E. Kinder. 1995. Melengestrol acetate at greater doses than typically used for estrus synchrony in bovine females does not mimic endogenous progesterone in regulation of secretion of luteinizing hormone and 17- $\beta$ Estradiol. Biol. Reprod., 52: 455-463.

Lamb, G.C., D.W. Nix, J.S. Stevenson and L.R. Corah. 2000. Prolonging the MGA prostaglandin F2 $\alpha$ interval from 17 to 19 days in an estrus synchronization system for heifers. Theriogenology 53:691-698.

National Research Council. 2001. Nutrient Requirements of Dairy Cattle. $7^{\text {th }}$ rev. ed. Natl. Acad. Sci., Washington, DC.

Nebel, R.L. and S.M. Jobst, 1998. Evaluation of systematic breeding programmes for lactating cows: a review. J. Dairy Sci., 81:1169-1174.

Odde, K. G. 1990. A review of synchronization of estrus in postpartum cattle. J. Anim. Sci. 68: 817-830.

Patterson, D.J. and L.R. Corah. 1992. Evaluation of a melengestrol acetate and prostaglandin $\mathrm{F} 2 \alpha$ system for the synchronization of estrus in beef heifers. Theriogenology, 38: 441-447. 
Patterson, D.J., D.J. Schafer and M.F. Smith. 2005. Review of estrus synchronization systems: MGA. Proceedings, Applied Reproductive Strategies in Beef Cattle November 12 and 13, 2005, Texas A\&M University, College Station.

Patterson, D.J., G.H. Kiracofe, J.S. Stevenson and L.R. Corah. 1989. Control of the bovine estrous cycle with melengestrol acetate (MGA): A review. J. Anim. Sci., 67: 1895-1906.

Patterson, D.J., J.E. Stegner, F.N. Kojima and M.F. Smith. 2002. MGA® Select improves estrus response in postpartum beef cows in situations accompanied with high rates of anestrous. Proc. West. Sec. Am. Soc. Anim. Sci. 53:418-420.

Perry, G.A., M.F. Smith and D.J. Patterson. 2002. Evaluation of a fixed-time artificial insemination protocol for postpartum suckled beef cows. J. Anim. Sci., 80: 3060-3064.

Repasi, A., Z. Szelenyi, G. Sassi, J. Reiczigel and O. Szenci. 2006. Effect of different prostaglandin protocols on fertility in dairy cows. Slov. Vet. Res. Ljubljana., 43: 1-338.

Short, R.E. and R.A. Bellows. 1971. Relationship among weight gains, age at puberty and reproductive performance in heifers. J. Anim. Sci. 32:127131.

Sirois, J., and J.E. Fortune. 1990. Lengthening the bovine estrous cycle with low levels of exogenous progesterone: a model for studying ovarian follicular dominance. Endocrinology, 127(2): 916-925.

Snedecor, G.W. and W.G. Cochran. 1989. Statistical Methods. lowa State University Press, Ames, IA.

Stegner, J.E., F.N. Kojima, M.R. Ellersieck, M.C. Lucy, M.F. Smith and D.J. Patterson. 2004a.A comparison of progestin-based protocols to synchronize estrus in postpartum beef cows.J.Anim.Sci.82:1016-1021.

Stegner, J.E., F.N. Kojima, M.R. Ellersieck, M.C. Lucy, M.F. Smith and D.J. Patterson. 2004b. Follicular dynamics and steroid profiles in cows during and after treatment with progestin-based protocols for synchronization of estrus. J. Anim. Sci., 82:1022-1028.

Stegner, J.E., J.F. Bader, F.N. Kojima, M.R. Ellersieck, M.F. Smith and D.J. Patterson. 2004c. Fixed-time artificial insemination of postpartum beef cows at 72 or 80 hours after treatment with the MGA®Select protocol. Theriogenology, 61:1299-1305.

Thundathil, J., J.P. Kastelic, W.O. Olson, R.B. Cook, and R.J. Mapletoft. 1999. Melengestrol acetate, estradiol-17 $\beta$ and $\mathrm{GnRH}$ for synchronization of estrus and ovulation in beef cows. Can. J. Anim. Sci., 39-43.

Twagiramungu, H., L.A. Guilbault and J.J. Dufour. 1995. Synchronization of ovarian follicular waves with a gonadotropin-releasing hormone agonist to increase the precision of estrus in cattle: A review. J. Anim. Sci., 73: 3141-3151.

Twagiramungu, H., L.A. Guilbault; J. Proulx, R. Ramkumar and J.J. Dufour. (1994). Histological populations and atresia of ovarian follicles in 
postpartum cattle treated with an agonist of gonadotropin-releasing hormone. J. Anim. Sci., 72:192-200.

Van Cleeff, J., M. Drost and W.W. Thatcher. 1991. Effects of postinsemination progesterone supplementation on fertility and subsequent estrous responses of dairy heifers. Theriogenology, 36: 795-807.

Wood, S.L., M.C. Lucy, M.F. Smith and D.J. Patterson. 2001. Improved synchrony of estrus and ovulation with addition of $\mathrm{GnRH}$ to a melengestrol acetate-prostaglandin $\mathrm{F} 2 \alpha$ estrus synchronization treatment in beef heifers. J. Anim. Sci., 79: 2210-2216.

Wright, M.F., B. Sayre, E.K. Inskeep, and J.A. Flores. 2001. Prostaglandin F2 $\alpha$ regulation of the bovine corpus luteum endothe lin system during the early and midluteal phase. Biol. Reprod., 65:1710-1717.

Yaniz, J. L.; K. Murugavel and F. Lopez-Gatius. (2004).Recent developments in oestrous synchronization of postpartum dairy cows with and without ovarian disorders. Reprod Domest Anim 39:86-93.

Yelich, J.V., R.D. Geisert, R.A.M. Schmitt, G.L. Morgan and J.P. McCann. 1997. Persistence of the dominant follicle during melengestrol acetate administration and its regression by exogenous estrogen treatment in beef cattle. J. Anim. Sci., 75: 745.

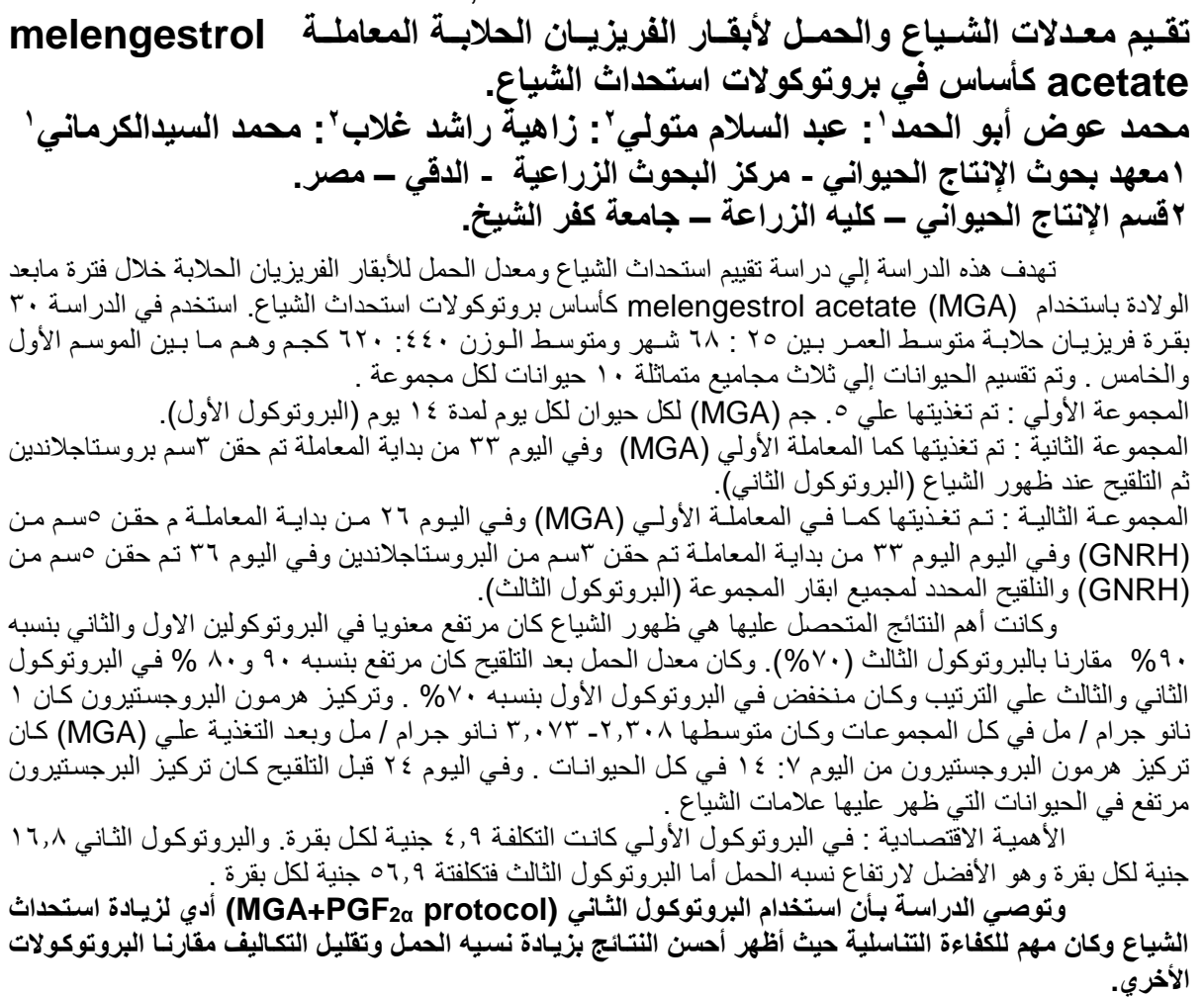

